\title{
Effect of Blending Doum (Hyphaene thebaica) Powder with Wheat Flour on the Nutritional Value and Quality of Cake
}

\author{
Hinar A. Seleem \\ Department of Crops Technology Research, Food Technology Research Institute, Agricultural Research Center, \\ Giza, Egypt \\ Email: hanhona853@hotmail.com
}

Received 17 April 2015; accepted 7 May 2015; published 8 May 2015

Copyright @ 2015 by author and Scientific Research Publishing Inc.

This work is licensed under the Creative Commons Attribution International License (CC BY). http://creativecommons.org/licenses/by/4.0/

(c) (i) Open Access

\section{Abstract}

Pastry is an essential part of food stuff people like, especially preferring those made of wheat flour: cakes, biscuits, pancakes, etc. The nutritive value of the products mentioned above is not high. Therefore, there is a need to increase it by adding something like doum fruit (Hyphaene thebaica L.), which is a widespread in Upper Egypt. Doum fruit is a rich source of fibers and antioxidants, also other valuable substances such as carbohydrates and minerals especially potassium (K for people suffering from blood pressure problems). This investigation was carried out to study the possibility of utilization doum fruit powder in cake production. Five levels of wheat flour substitution were used $0 \%, 5 \%, 10 \%, 15 \%$ and $20 \%$ to produce cake. Also, the effects of blends on farinograph parameters were studied. Results indicated that substitution of doum powder (D.P) led to increase the water absorption (\%) and dough weakening (B.U), whereas dough stability (min) was decreased. The water holding capacity of blends increased with increasing the level of substitution. The chemical, physical and sensory characteristics of the prepared cakes were studied. Results showed that increasing the levels of substitution increased the total fat, crude fiber and ash contents in produced cake compared with control. Minerals of the produced cake showed an increment in $\mathrm{K}$ and $\mathrm{Mg}$, while slightly increment in $\mathrm{Ca}$, Fe and $\mathrm{Zn}$ with increasing the level of substitution. Total phenol and antioxidant activity (AO) increased in substituted cake. Physical attributes of the produced cakes were evaluated and results showed that volume of substituted cakes decreased with increasing the level of replacement except for $10 \%$ level it increased. Results of textural analysis showed that D.P fiber decreased all the parameters. Concerning cake color, as the percentage of D.P increased, the color of the cake became darker and had high a and $b$ values. The sensory evaluation results showed an insignificantly decrease in the acceptability by increasing the doum powder substitution comparing with control. 


\section{Keywords}

\section{Doum Fruit, Wheat Flour, Cake, Rheological, Physicochemical, Sensory Properties}

\section{Introduction}

Doum fruit, (Hyphaene thebaica) is a desert palm growing wild throughout the drier regions in Egypt, (SubSaharan) Africa, and west India. It listed as one of the useful plants of the world [1]. It has been cultivated in Egypt since immemorial times. (Such plant is mentioned as garden tree under the name of MAMA which means it has forked stems with fan shaped leaves, with a flat surface of approximately $66 \mathrm{~cm} \mathrm{long).}$

The mesocarp of the fruit is usually eaten by children of primary and secondary school due to its delicious and sweet taste. To the people of the desert where doum palms are found, it is life sustaining and is listed as a famine food. Doum is one of commonly consumed beverages in traditional places in Egypt. The drink has been prepared from the fruits by infusing the dried ground fruit pulp in hot water. This drink is widely consumed as a health tonic as a remedy for hypertension [2].

Doum fruits are relatively rich in protein and in essential minerals. It contains high amount of essential minerals which in most instances exceed the recommended daily allowance (RDA), and thus may keep the balance and ratios between those in need [3]. Doum was reported to lower the blood pressure, when its biological activity was evaluated in rat feeding experiments [4] [5].

It has been reported that $\mathrm{Na} / \mathrm{K}$ ratios less than one have a great importance in the body for the control of high blood pressure [6]. A food or feed source is considered good if the $\mathrm{Ca} / \mathrm{P}$ ratio is above one and poor if the ratio is less than 0.50 [7].

The high fiber content of doum fruit is suggesting as a potential to be used in the formulation of bakery products such as bread, biscuits, cookies, cakes and pan cakes to satisfy consumer needs for increased fiber intake without sacrificing sensory attributes and enrich their texture, flavor and nutritional value [8] [9]. Besides, it is great contribution to the health and wellbeing of humankind by preventing the gastrointestinal problems such as constipation and therefore, it is regarded as a natural anti colon cancer [10]. Doum pulp contains $4.91 \%$ proteins, $5.26 \%$ fat, $4.50 \%$ ash and $85.33 \%$ total carbohydrate [11].

The current focus is toward natural antioxidant especially plant polyphenolics [12]-[14]. Doum is rich in polyphenolic compounds; its extract contains $1.20 \mu \mathrm{g} / \mathrm{g}$ dried plant extract as Gallic and $3.70 \mu \mathrm{g} / \mathrm{g}$ dried plant extract as quercetin which act to reduce the oxidative stress by scavenging free radicals [13] [15]-[17].

Bakery products constitute one of the most consumed foods in the world. Among them, cakes are popular and are associated in the consumer's mind with a delicious sponge product with desired organoleptic characteristics [18].

The objectives of this study were to use doum fruit powder as a rich source of fiber and as a functional ingredient in cake production and to evaluate the effect of substitution of wheat flour with doum powder on physical, rheological and sensory characteristics of cake.

\section{Materials and Methods}

\subsection{Materials}

Wheat flour (72\% extraction rate) was obtained from South Cairo Company of milling. Sugar, baking powder, corn oil, salt, eggs, skim milk and vanilla were purchased from the super market. Doum fruit flakes (Hyphaene thebaica) were obtained from El Khateeb Company, Giza, Egypt. All chemicals were of the analytical reagent grade.

\subsection{Methods}

\subsubsection{Preparation of Doum Powder (D.P)}

Dry doum fruit flakes were ground electrically in laboratory mill (JKA-Labora technic, Janke and Kunkel Type: MFC, Germany) to pass through 80 mesh sieve, then packed and stored in a refrigerator $\left(4^{\circ} \mathrm{C}\right)$ until used. 


\subsubsection{Cake Preparation}

Cakes were prepared from substitution blends containing $0 \%, 5 \%, 10 \%, 15 \%$ and $20 \%$ of Doum Powder (D.P). The formula included $100 \mathrm{~g}$ wheat flour, (72\% extraction rate) and substituted blends as shown in Table 1 . Dry ingredients, corn oil and half milk were mixed at low speed for 30 sec with a wire whip in a $4-7 \mathrm{l}$ bowl of an electric mixer (Moulinex, France). After the bowl was scraped, mixing was continued half remain milk was added, and the batter was mixed 30 sec on low speed. The remaining milk was added, the butter was mixed for 20 sec on low speed, the bowl was scraped, and mixing was continued for 30 sec on low speed. The cake batter was immediately deposited into round cake pans. For each cake (82 $\mathrm{g}$ batter) was poured into a cake pan and baked at $180^{\circ} \mathrm{C}$ for $25 \mathrm{~min}$ in preheated electric oven (Kumtel, Turkey). The cakes were allowed to cool for $1 \mathrm{~h}$ and were then removed from the pans. Each treatment contains eight replicates for all tests. The cooled cakes were sensory evaluate and packed in a polyethylene bags at room temperature before analysis [9].

\subsubsection{Analytical Methods}

The proximate chemical composition i.e. moisture, crude protein, total fat, ash and crude fiber of raw materials and cake samples were determined according to AOAC [19]. Total carbohydrate were calculated by difference.

\subsubsection{Rheological Properties}

Water absorption, dough development, stability and dough weakening of wheat flour and its blends were determined by using farinograph (Brabender Duisburg, Germany) according to the methods described in AACC [20].

\subsubsection{Water Holding Capacity (WHC)}

Water holding capacities (WHC) of doum powder (D.P), wheat flour (72\% extraction) and substituted doum flour (blends) $5 \%, 10 \%, 15 \%$ and $20 \%$ were determined according to AACC [20].

\subsubsection{Determination of Macro and Micro Elements for Doum Powder (D.P) and Substituted Doum Cake}

Two grams of sample was weighed and heated at $550^{\circ} \mathrm{C}$. Then the ashes were dissolved with $100 \mathrm{ml} 1 \mathrm{M} \mathrm{HCl}$. Dissolved ash was analyzed for sodium, potassium, magnesium, calcium, iron and zinc content by using methods of AOAC [19]. Perkin Elmer (Model 3300, USA) atomic absorption spectrophotometer was used to determine these minerals. Phosphorus content was calorimetrically determined by spectrophotometer at $650 \mathrm{~nm}$ according to the method described in AOAC [19].

\subsubsection{Total Phenol}

The total phenol were estimated according to the Folin-Ciocalteu [21]. Gallic acid was chosen as a standard to

Table 1. Cakes formula prepared with doum fruit powder at different levels of substitutions.

\begin{tabular}{cc}
\hline Ingredients & Level (g) \\
Wheat flour & $80-100$ \\
Sugar & 75 \\
Doum powder (D.P) & $5-20$ \\
Corn oil & 20 \\
Whole eggs & 60 \\
Skim milk & 7.0 \\
Water & 45 \\
Baking powder & 3.0 \\
Vanilla & 0.3 \\
Salt & 0.2 \\
\hline
\end{tabular}

\footnotetext{
* $7 \mathrm{~g}$ solved in $45 \mathrm{ml}$ water.
} 
prepare the standard curve. Phenols were expressed as mg/100g sample on dry weight basis.

\subsubsection{Antioxidant Activity Assays}

The DPPH (2.2-diphenyl-1-picrylhydrazydl) radical scavenging activity of methanolic extracts was determined following the method reported by Tepe et al. [22].

\subsubsection{Physical Measurements of Cake}

Cake weight (g) was recorded after cooling for1hr. Cake volume $\left(\mathrm{cm}^{3}\right)$ was determined by rapeseed displacement method as described by AACC [20]. Specific volume $\left(\mathrm{cm}^{3} / \mathrm{g}\right)$ of cake was calculated by dividing volume by weight. Density $\left(\mathrm{g} / \mathrm{cm}^{3}\right)$ was calculated by dividing weight by volume.

\subsubsection{Texture Profile Analysis (TPA) of Cake}

Cake texture was determined by universal testing machine (Conetech, B type, Taiwan) provided with software according to Bourne [23]. An aluminum $25 \mathrm{~mm}$ diameter cylindrical probe was used in a TPA double compression test to penetrate to 50\% depth, at $1 \mathrm{~mm} / \mathrm{s}$ speed test. Firmness (N), gumminess (N) chewiness $(\mathrm{N})$, cohesiveness and springiness were calculated from TPA graphic.

\subsubsection{Color Evaluation}

The color of cake crumb was measured according to the method outlined by [24] crumb color was measured on opposite sides of cake by using a hand-held tristimulus reflectance Colorimeter Minolta chromammeter (model CR-400, Konica Minolta, Japan). The apparatus provided L (lightness with $\mathrm{L}=100$ for lightness, and $\mathrm{L}=$ zero for darkness), a [(chromaticity on green $(-)$ to red $(+)$ ], b [(chromaticity on a blue $(-)$ to yellow $(+)$ ], c (color saturation $)$, h $\left[\left(\right.\right.$ hue angle were $0^{\circ}=$ red to purple, $90^{\circ}=$ yellow, $180^{\circ}=$ bluish to green and $270^{\circ}=$ blue $]$ scale .

\subsubsection{Sensory Evaluation of Cake}

Cake samples were organoleptically evaluated for its sensory characteristics. Slice of each cake sample was served for ten panelists on white, odorless and disposable plates. Samples were scored for shape, crust color, crust characteristics, crumb color, brightness, crumb texture, softness, taste, odor and total score. The evaluation was carried out according to Bennion and Bamford [25].

\subsection{Statistical Analysis}

For the analytical data, mean values and standard deviation are reported. The data obtained were subjected to one-way analysis of variance (ANOVA) at $\mathrm{P}<0.05$.

\section{Results and Discussion}

\subsection{Farinograph Parameters}

The effect of substitution wheat flour with different levels of doum fruit powder (5\%, 10\%, $15 \%$ and $20 \%)$ on farinograph parameters was cleared in Table 2. From Table 2, it could be observed that, water absorption of wheat flour dough and wheat flour blended with different levels of doum fruit powder increased from $62.8 \%$ to

Table 2. Farinograph parameters of wheat flour dough and doum fruit powder blends with different substitutions.

\begin{tabular}{|c|c|c|c|c|c|}
\hline Parameters & $\begin{array}{c}\text { Water absorption } \\
\text { (\%) }\end{array}$ & $\begin{array}{l}\text { Arrival time } \\
\text { (min) }\end{array}$ & $\begin{array}{l}\text { Dough development } \\
\text { (min) }\end{array}$ & $\begin{array}{l}\text { Stability } \\
\text { (min) }\end{array}$ & $\begin{array}{l}\text { Dough weakening } \\
\text { (B.U) }\end{array}$ \\
\hline $100 \%$ W.F (72\% extraction) & 62.8 & 0.5 & 1.0 & 4.0 & 80 \\
\hline 5\% D.P & 63.7 & 1.5 & 2.0 & 3.5 & 90 \\
\hline 10\% D.P & 64.0 & 2.0 & 2.5 & 3.0 & 100 \\
\hline 15\% D.P & 64.5 & 3.0 & 3.5 & 2.5 & 120 \\
\hline 20\% D.P & 65.3 & 3.5 & 5.0 & 2.0 & 130 \\
\hline
\end{tabular}

D.P = doum powder. $\mathrm{W} \cdot \mathrm{F}=$ wheat flour. 
$65.3 \%$ by increasing the levels to $20 \%$ compared with control dough ( $100 \%$ wheat flour). These results are in agreement with Holloway and Grieg [26] who mentioned that the doum fruit flour increases the water absorption, due to high fiber content. Also, the same trend was observed in the arrival time and dough development.

This increment may be due to high amount of crude fiber in doum fruit which effect on dough properties. It could be observed from that, $100 \%$ wheat flour dough (control) had the lowest development time (1 min), which increased upon replacing wheat flour with (D.P). Dough development time increased from 1.0 to 5.0 min. Dough stability, which is an indicator to dough strength decreased in dough samples from 4.0 to 2.0 min by increasing the level of substitution with (D.P), while weakening increased from 80 to $130 \mathrm{BU}$ which is due to dilution of gluten protein from wheat flour with the increase fiber content from (D.P). This may also be due to the interaction between fibrous materials and gluten, which affects the dough mixing properties as reported by Shouk and Ramadan [27].

\subsection{Water Holding Capacity}

Water holding capacity of doum fruit powder, wheat flour (72\% ext.) and their blends (5\%, 10\%, 15\% and 20\%) illustrated in Figure 1. From data in Figure 1 it could be observed that the doum fruit powder has the highest water holding capacity $(3.32 \mathrm{~g} / \mathrm{g})$, whereas wheat flour has the lowest value $(1.99 \mathrm{~g} / \mathrm{g})$. This means that the doum powder absorbed more water than wheat flour. By increasing the level of doum fruits powder, the water holding capacity increased. This may be attributes to the high fiber content of the doum fruit powder. This result is in agreement with Holloway and Grieg [26] who found that the high fiber content of doum fruit led to high water holding capacity.

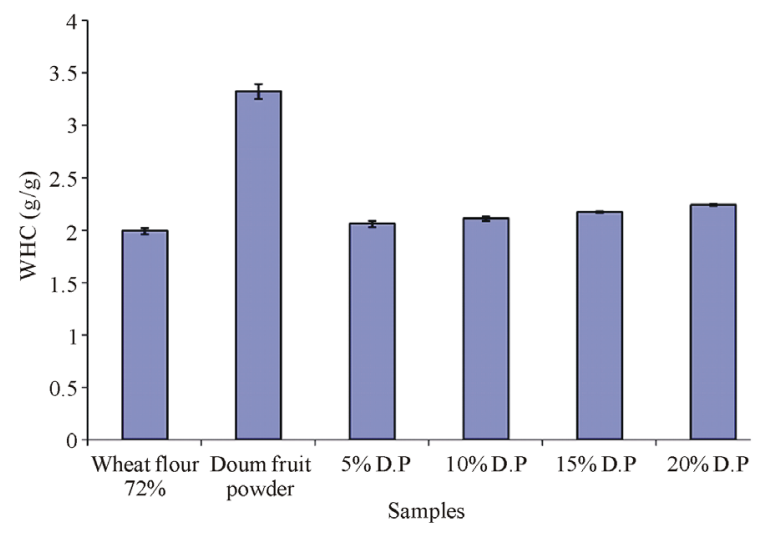

Figure 1. Water holding capacity of wheat flour, doum powder and substituted blends.

\subsection{Chemical Composition}

Chemical composition of wheat flour and doum fruit powder was given in Table 3. Data showed that wheat flour had higher levels of protein and carbohydrate content $(11.63 \%$ and $85.63 \%)$ than doum powder $(7.05 \%$ and $62.72 \%)$, respectively. While doum powder had higher levels of fat, crude fiber and ash content $(2.57 \%, 20.88 \%$ and $6.60 \%$ ) than wheat flour $72 \%$ extraction (1.50\%, $0.73 \%$ and $0.52 \%)$, respectively. From the above mentioned

Table 3. Chemical composition of raw materials (\% dry weight).

\begin{tabular}{ccc}
\hline Components (\%) & Wheat flour (72\% extraction rate) & Doum fruit powder \\
Protein & $11.63 \pm 0.11^{\mathrm{a}}$ & $7.05 \pm 0.21^{\mathrm{b}}$ \\
Total fat & $1.50 \pm 0.12^{\mathrm{b}}$ & $2.57 \pm 0.10^{\mathrm{a}}$ \\
Crude fiber & $0.73 \pm 0.10^{\mathrm{b}}$ & $20.88 \pm 0.30^{\mathrm{a}}$ \\
Ash & $0.52 \pm 0.09^{\mathrm{b}}$ & $6.60 \pm 0.20^{\mathrm{a}}$ \\
Total carbohydrate & $85.63 \pm 0.39^{\mathrm{a}}$ & $62.72 \pm 0.9^{\mathrm{b}}$ \\
\hline
\end{tabular}

Values are mean of three replicates \pm SD, number in the same row followed by the same letter are not significantly different at 0.05 leve1. 
data, it was cleared that wheat flour was rich in protein and carbohydrates while poor in fat, fiber and ash content. Whereas, doum powder was rich in the last three components. These results are in agreement with those obtained by Hashem [2] and Abd El-Latteef et al. [28].

Table 4 showed chemical composition of the produced cake substitutes with $5 \%, 10 \%, 15 \%$ and $20 \%$ of doum fruit powder. Cake substitutes with doum powder at different levels showed significant differences for total fat, crude fiber and ash content relative to control cake and this may be due to the higher content of total fats, crude fiber and ash in doum fruit powder. Total carbohydrates of substituted cake decreased significantly compared with control cake. This may be due to low amount of carbohydrates in doum fruit powder compared with wheat flour. At the same time, there were significant differences in total carbohydrates content between doum cake at $5 \%$ and $10 \%$ levels.

Table 4. Chemical composition of produced cake with different substitutions (\% on dry weight basis).

\begin{tabular}{cccccc}
\hline Samples & Protein & Total fats & Crude fiber & Ash & Total carbohydrates \\
\hline Control (100\% W.F) & $13.97 \pm 0.20^{\mathrm{a}}$ & $16.41 \pm 0.10^{\mathrm{e}}$ & $0.75 \pm 0.05^{\mathrm{d}}$ & $0.85 \pm 0.03^{\mathrm{e}}$ & $68.02 \pm 0.18^{\mathrm{a}}$ \\
5\% D.P & $13.82 \pm 0.20^{\mathrm{a}}$ & $16.81 \pm 0.20^{\mathrm{d}}$ & $2.37 \pm 0.04^{\mathrm{c}}$ & $0.93 \pm 0.05^{\mathrm{d}}$ & $66.04 \pm 0.44^{\mathrm{b}}$ \\
10\% D.P & $13.35 \pm 0.10^{\mathrm{b}}$ & $17.21 \pm 0.10^{\mathrm{c}}$ & $3.62 \pm 0.05^{\mathrm{b}}$ & $1.45 \pm 0.01^{\mathrm{c}}$ & $64.37 \pm 0.36^{\mathrm{c}}$ \\
15\% D.P & $13.12 \pm 0.90^{\mathrm{bc}}$ & $17.61 \pm 0.30^{\mathrm{b}}$ & $3.93 \pm 0.10^{\mathrm{a}}$ & $1.91 \pm 0.05^{\mathrm{b}}$ & $63.43 \pm 0.65^{\mathrm{d}}$ \\
20\% D.P & $12.90 \pm 0.11^{\mathrm{c}}$ & $18.00 \pm 0.20^{\mathrm{a}}$ & $4.02 \pm 0.03^{\mathrm{a}}$ & $2.04 \pm 0.04^{\mathrm{a}}$ & $63.03 \pm 0.37^{\mathrm{d}}$ \\
\hline
\end{tabular}

D.P = doum powder. W.F = wheat flour. Values are mean of three replicates \pm SD, number in the same column followed by the same letter are not significantly different at 0.05 leve1.

\subsection{Minerals Content of Doum Powder and Substituted Cake}

Doum fruit powder, wheat flour cake and substituted doum cake were analyzed for phosphorus, calcium, iron, potassium, sodium, magnesium and zinc as presented in Table 5. Results show that minerals content were varied according to the raw materials and the levels of substitution. Minerals content of doum fruit powder showed the highest contents of calcium (Ca), magnesium (Mg), potassium (K), iron $(\mathrm{Fe})$ and zinc $(\mathrm{Zn})$ except for phosphorus (P) and sodium ( $\mathrm{Na}$ ) compared with wheat flour cake. P content of control and cake substituted with doum powder was decreased from 190.01 to $182.95 \mathrm{mg} / 100 \mathrm{~g}$, while Na content of cakes increased from 579.14 to $634.06 \mathrm{mg} / 100 \mathrm{~g}$. Replacing wheat flour by doum powder increased the macro minerals concentration in produced cake relative to the control sample.

The greatest increasing rate observed in magnesium (95.38\%) followed by K (57.18\%) in 20\% substituted cake sample. While, sodium concentration increased in the same sample (9.48\%).

Phosphorus content slightly decreased in all samples with increasing substitution. While calcium (Ca) content slightly increased compared with control. Doum fruit contains higher amounts of essential minerals which in most instances exceed the recommended daily allowance (RDA), thus may keep the balances and ratios between those in need. These results are due to the doum powder is good source of these minerals. The $\mathrm{Na} / \mathrm{K}$ ratio less

Table 5. Minerals of doum fruit powder and produced cake with different substitutions.

\begin{tabular}{ccccccccccc}
\hline \multirow{2}{*}{ Samples } & \multicolumn{9}{c}{ Minerals (mg/100g sample) } \\
\cline { 2 - 10 } & $\mathrm{P}$ & $\mathrm{Ca}$ & $\mathrm{Fe}$ & $\mathrm{K}$ & $\mathrm{Na}$ & $\mathrm{Mg}$ & $\mathrm{Zn}$ & $\mathrm{Ca} / \mathrm{P}$ & $\mathrm{Na} / \mathrm{K}$ \\
\hline Doum powder & 150.00 & 30.0 & 5.55 & 1451.69 & 274.65 & 217.16 & 0.48 & 0.20 & 0.19 \\
Control cake (100\% W.F.) & 190.01 & 17.40 & 4.80 & 507.70 & 579.14 & 42.01 & 0.43 & 0.09 & 1.14 \\
5\% D.P & 188.10 & 18.90 & 4.83 & 580.28 & 592.87 & 53.89 & 0.44 & 0.10 & 1.02 \\
10\% D.P & 186.50 & 20.40 & 4.86 & 652.86 & 606.60 & 63.99 & 0.48 & 0.10 & 0.93 \\
15\% D.P & 184.25 & 21.90 & 5.00 & 725.44 & 620.33 & 71.22 & 0.50 & 0.12 & 0.86 \\
20\% D.P & 182.95 & 23.87 & 5.03 & 798.02 & 634.06 & 82.08 & 0.52 & 0.13 & 0.79 \\
\hline
\end{tabular}

D.P = doum powder. W.F. = wheat flour. 
than one with increasing the levels of substitution (10\%, $15 \%$ and $20 \%)$. The $\mathrm{Ca} / \mathrm{P}$ ratio is poor because it is less than one (ranged from 0.09 to 0.13 for control cake and substituted cake at $20 \%$, respectively). These results are in agreement with Aremu et al. [6] and Nieman et al. [7].

Concerning to micro minerals concentrations, data showed slight increase in iron (Fe) and zinc (Zn) levels for substituted cake. This may be due to the concentration of zinc and iron in wheat flour and doum powder are nearly equal.

From the above mentioned data, the produced cakes have good amount of $\mathrm{K}$, so they are considered an advantage for people suffering from blood pressure problems.

\subsection{Total Phenol and Antioxidant Activity (A0) in Doum Fruit Powder, Wheat Flour Cake and Substituted Cake with Doum Fruit Powder at Different Levels}

Doum fruit powder, wheat flour cake (control) and substituted doum cake were analyzed for total phenol and antioxidant activity (AO) (Table 6, Figure 2). Data given in Table 6 indicated that doum fruit powder has higher total phenol content $(122.55 \mathrm{mg} / 100 \mathrm{~g})$ than wheat flour cake $(22.96 \mathrm{mg} / 100 \mathrm{~g})$. Substitution of wheat flour with doum fruit powder caused a significant increase in total phenol content proportionally with increasing the substitution level. The highest value was noticed at $20 \%$ (66.92 mg/100g) compared with control (22.96 $\mathrm{mg} / 100 \mathrm{~g}$ ) and the other cake samples.

Same trend was observed in antioxidant activity (AO) of the produced cake. Data revealed that doum fruit powder had high DPPH scavenging activity (86.00\%) compared with wheat flour cake (6.84\%). Increasing the level of replacement, the high value of antioxidant activity (AO) of cake was observed and there were significant differences between cake samples. The antioxidant activity of cakes ranged from $6.84 \%$ for control and $56.71 \%$ for $20 \%$ substitution level. The high value of antioxidant activity for substituted cake samples could be attributed to the high total phenol content of doum fruit powder (Figure 2 and Table 6). These results are in agreement with Abou-Elalla [16] who mentioned that the aqueous extract of doum fruits showed an antioxidant activity, this is due to the substantial amount of their water soluble phenolic content.

\section{Table 6. Total phenol of doum fruit powder and produced cake with different substitutions.}

\begin{tabular}{|c|c|}
\hline Parameter & Total phenol (mg/100g) \\
\hline Doum fruit powder & $122.55 \pm 1.77^{\mathrm{a}}$ \\
\hline Control cake & $22.96 \pm 0.79^{f}$ \\
\hline 5\% D.P & $34.86 \pm 0.01^{\mathrm{e}}$ \\
\hline 10\% D.P & $41.65 \pm 1.19^{\mathrm{d}}$ \\
\hline 15\% D.P & $50.32 \pm 2.32^{c}$ \\
\hline $20 \%$ D.P & $66.92 \pm 3.08^{\mathrm{b}}$ \\
\hline
\end{tabular}

D.P = doum powder. Values are mean of three replicates \pm SD, number in the same column followed by the same letter are not significantly different at 0.05 leve 1 .

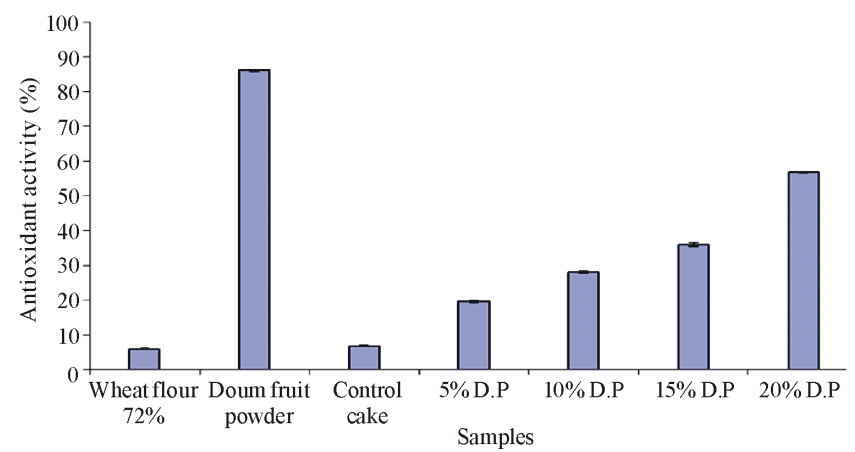

Figure 2. Antioxidant activity (AO) of wheat flour, doum powder and produced cake with different substitutions. 


\subsection{Physical Properties of Cake}

Physical attributes (weight, volume, specific volume and density) of wheat flour cake and substituted cakes are given in Table 7. According to weight data showed no significant difference between control cake and $10 \%$ substituted cake, also between $15 \%$ and $20 \%$. Substituted cake at level $10 \%$ has the highest volume (130.50 $\mathrm{cm}^{3}$ ), while the volume began to decrease with increasing the level of substitution to reach $107.0 \mathrm{~cm}^{3}$ Concerning to specific volume $\left(\mathrm{cm}^{3} / \mathrm{g}\right)$, the results indicated that substituted cake at $10 \%$ level had the highest specific volume $\left(3.46 \mathrm{~cm}^{3} / \mathrm{g}\right)$ relative to other samples. On the other hand, density of the same cake sample decreased to $0.29 \mathrm{~g} / \mathrm{cm}^{3}$ compared with control cake $\left(0.33 \mathrm{~g} / \mathrm{cm}^{3}\right)$ and other substituted cakes.

\subsection{Texture Analysis of Cake Produced from Wheat Flour Substituted with Different Levels of Doum Fruit Powder}

The texture parameters assessed from Texture Profile Analysis (TPA) curves are presented in Table 8. A slight decrease in firmness from 1.80 to $1.39 \mathrm{~N}$ was found. On the other hand, the cake became softer with increasing doum powder levels.

Results showed a decrease in cakes cohesiveness and springiness relative to control, whereas there were no significant differences between substituted cake samples with increasing the levels of doum powder in the same parameters. Furthermore, the gumminess parameter was decreased with increasing level of doum powder.

The same trend was observed in chewiness parameter. Overall, doum fruit powder decreased all the TPA parameters, this is connected with the fiber ability in doum powder to detain moisture in wheat flour products. These results are in agreement with Fondroy et al. [9] and Gedrovica and Karklina [29] who mentioned that as the amount of cellulose was increased in the formation, the cake become softer. Coimbra and Jorge [10] found that high fiber content of doum fruit is enriching bakery products texture.

\subsection{Color Measurements of Cake Samples}

Color values ( $\mathrm{L}, \mathrm{a}, \mathrm{b}, \mathrm{c}$ and $\mathrm{h}$ ) were showed in Table 9. Color values lightness and redness ( $\mathrm{L}$ and a) are vary with control cake, also yellowness (b) was vary with the control, but there is no significant difference between $10 \%$ and $15 \%$ substituted cake. However, as the level of substitution was increased, the cake crumb become

Table 7. Physical properties of produced cake with different substitutions.

\begin{tabular}{|c|c|c|c|c|c|}
\hline Parameters Samples & $\begin{array}{c}\text { Control cake } \\
\text { (100\% wheat flour) }\end{array}$ & 5\% D.P & 10\% D.P & 15\% D.P & 20\% D.P \\
\hline Weight (g) & $38.28 \pm 0.52^{\mathrm{a}}$ & $37.57 \pm 0.08^{b}$ & $37.70 \pm 0.34^{\mathrm{ab}}$ & $36.56 \pm 0.03^{\mathrm{c}}$ & $36.86 \pm 0.36^{\mathrm{c}}$ \\
\hline Volume $\left(\mathrm{cm}^{3}\right)$ & $116.70 \pm 3.05^{\mathrm{b}}$ & $109.30 \pm 3.06^{\mathrm{c}}$ & $130.50 \pm 0.5^{\mathrm{a}}$ & $108.50 \pm 0.51^{c}$ & $107.0 \pm 3.00^{c}$ \\
\hline Specific volume $\left(\mathrm{cm}^{3} / \mathrm{g}\right)$ & $3.04 \pm 0.09^{b}$ & $2.91 \pm 0.08^{\mathrm{b}}$ & $3.46 \pm 0.03^{b}$ & $2.94 \pm 0.05^{\mathrm{b}}$ & $2.89 \pm 0.14^{\mathrm{b}}$ \\
\hline Density $\left(\mathrm{g} / \mathrm{cm}^{3}\right)$ & $0.33 \pm 0.01^{\mathrm{b}}$ & $0.34 \pm 0.01^{\mathrm{a}}$ & $0.29 \pm 0.01^{\mathrm{c}}$ & $0.34 \pm 0.01^{\mathrm{a}}$ & $0.34 \pm 0.01^{\mathrm{a}}$ \\
\hline
\end{tabular}

D.P = doum powder. Values are mean of three replicates \pm SD, number in the same row followed by the same letter are not significantly different at 0.05 leve1.

Table 8. Texture analysis of produced cake with different substitutions.

\begin{tabular}{|c|c|c|c|c|c|}
\hline $\begin{array}{l}\text { Parameters } \\
\text { Samples }\end{array}$ & Firmness (N) & Cohesiveness & Gumminess (N) & Chewiness $(\mathrm{N})$ & Springiness \\
\hline Control cake & $1.80 \pm 0.03^{\mathrm{a}}$ & $0.68 \pm 0.01^{\mathrm{a}}$ & $1.21 \pm 0.02^{\mathrm{a}}$ & $0.77 \pm 0.02^{\mathrm{a}}$ & $0.65 \pm 0.01^{\mathrm{a}}$ \\
\hline 5\% D.P & $1.62 \pm 0.01^{\mathrm{a}}$ & $0.48 \pm 0.01^{\mathrm{b}}$ & $0.79 \pm 0.01^{b}$ & $0.40 \pm 0.01^{\mathrm{b}}$ & $0.50 \pm 0.01^{b}$ \\
\hline 10\% D.P & $1.59 \pm 0.03^{b}$ & $0.46 \pm 0.01^{\mathrm{b}}$ & $0.72 \pm 0.01^{\mathrm{bc}}$ & $0.37 \pm 0.01^{\mathrm{b}}$ & $0.52 \pm 0.01^{b}$ \\
\hline 15\% D.P & $1.47 \pm 0.14^{\mathrm{bc}}$ & $0.46 \pm 0.04^{\mathrm{b}}$ & $0.69 \pm 0.06^{\mathrm{cd}}$ & $0.36 \pm 0.03^{\mathrm{b}}$ & $0.49 \pm 0.04^{b}$ \\
\hline 20\% D.P & $1.39 \pm 0.03^{\mathrm{c}}$ & $0.43 \pm 0.01^{\mathrm{b}}$ & $0.61 \pm 0.01^{\mathrm{d}}$ & $0.30 \pm 0.01^{\mathrm{c}}$ & $0.47 \pm 0.01^{\mathrm{b}}$ \\
\hline
\end{tabular}

D.P = doum powder. Values are mean of three replicates \pm SD, number in the same column followed by the same letter are not significantly different at 0.05 leve1. 
darker (lower L values), slightly more yellow (b values) specially for $20 \%$ levels of substitution, and more redness (a values) increased with increasing the levels of substitution comparing with control (lower negative a value -0.39 ).

The b values were only slightly affected by levels of substitution. On the other hand, c (color saturation) increased with increasing the level of substitution, from yellow to orange yellow. The hue angle (h) decreased significantly in substituted cake comparing with control, then the color of the cake gradually change from yellow to orange yellow for $10 \%$ to $20 \%$ level of substitution.

\subsection{Sensory Evaluation}

Sensory evaluation score for the cakes substituted with different level of doum powder are illustrated in Table 10. The results showed that there are no significant differences between substituted samples in shape and crust color. Also, there are no significant differences in crust characteristics, and odor between samples and control. On the other hand, there are significant differences in crumb color and brightness between samples and control, also brightness decreased significantly with increasing the level of substitution. Crumb texture slightly decreased with increasing the level of substitution, while there are no significant differences in softness between samples and control. Taste slightly decreased in substituted cake sample at $20 \%$ level compared with control, but there were no significant differences between substituted cake (5\%, 10\% and 15\%) and control cake.

Results in Table 10 clearly indicated that using doum fruit powder in cake at levels 5\%, 10\%, 15\% and 20\%

Table 9. Color measurements of produced cake with different substitutions.

\begin{tabular}{|c|c|c|c|c|c|}
\hline Parameters $\quad$ Treatments & Control & 5\% D.P & 10\% D.P & 15\% D.P & 20\% D.P \\
\hline $\mathrm{L}$ & $62.58 \pm 1.05^{\mathrm{a}}$ & $56.21 \pm 0.21^{b}$ & $48.29 \pm 0.26^{c}$ & $47.65 \pm 0.05^{c}$ & $46.27 \pm 0.31^{d}$ \\
\hline $\mathrm{a}$ & $-0.39 \pm 0.04^{\mathrm{e}}$ & $3.39 \pm 0.02^{\mathrm{d}}$ & $5.41 \pm 0.17^{c}$ & $6.33 \pm 0.28^{\mathrm{b}}$ & $7.47 \pm 0.41^{\mathrm{a}}$ \\
\hline $\mathrm{b}$ & $28.36 \pm 0.02^{d}$ & $28.91 \pm 0.07^{c}$ & $29.62 \pm 0.19^{b}$ & $29.78 \pm 0.16^{\mathrm{b}}$ & $30.94 \pm 0.09^{\mathrm{a}}$ \\
\hline C & $28.36 \pm 0.28^{\mathrm{e}}$ & $28.91 \pm 0.07^{\mathrm{d}}$ & $29.38 \pm 0.24^{c}$ & $30.28 \pm 0.25^{b}$ & $31.67 \pm 0.15^{\mathrm{a}}$ \\
\hline $\mathrm{h}$ & $90.76 \pm 0.07^{\mathrm{a}}$ & $83.13 \pm 0.05^{b}$ & $79.72 \pm 0.29^{c}$ & $78.60 \pm 0.29^{d}$ & $77.60 \pm 0.25^{\mathrm{e}}$ \\
\hline Color & Yellow & Yellow & Orange yellow & Orange yellow & Orange yellow \\
\hline
\end{tabular}

D.P = doum powder. Values are mean of three replicates \pm SD, number in the same row followed by the same letter are not significantly different at 0.05 leve1. $\mathrm{L}$ (lightness with $\mathrm{L}=100$ for lightness, and $\mathrm{L}=$ zero for darkness), a [(chromaticity on green $(-)$ to red $(+)]$, b $[($ chromaticity on a blue $(-)$ to yellow $(+)]$, c (color saturation), h $\left[\left(\right.\right.$ hue angle were $0^{\circ}=$ red to purple, $90^{\circ}=$ yellow, $180^{\circ}=$ bluish to green and $270^{\circ}=$ blue $]$ scale.

Table 10. Sensory evaluation of produced cake with different substitutions.

\begin{tabular}{|c|c|c|c|c|c|}
\hline Samples & Control & 5\% D.P & $10 \%$ D.P & 15\% D.P & 20\% D.P \\
\hline Shape (10) & $9.78 \pm 0.42^{\mathrm{a}}$ & $8.89 \pm 0.78^{b}$ & $8.78 \pm 0.83^{b}$ & $8.72 \pm 0.90^{b}$ & $8.56 \pm 1.33^{b}$ \\
\hline Crust color (10) & $9.5 \pm 0.50^{\mathrm{a}}$ & $8.06 \pm 0.88^{\mathrm{b}}$ & $8.06 \pm 1.18^{\mathrm{b}}$ & $8.17 \pm 1.22^{\mathrm{b}}$ & $7.61 \pm 1.32^{\mathrm{b}}$ \\
\hline Crust characteristics (10) & $9.56 \pm 0.53^{\mathrm{a}}$ & $9.06 \pm 1.07^{\mathrm{a}}$ & $8.72 \pm 0.94^{\mathrm{a}}$ & $8.67 \pm 1.30^{\mathrm{a}}$ & $8.50 \pm 1.27^{\mathrm{a}}$ \\
\hline Crumb color (10) & $9.78 \pm 0.44^{\mathrm{a}}$ & $8.67 \pm 0.71^{b}$ & $8.39 \pm 0.49^{b c}$ & $7.72 \pm 1.03^{\mathrm{cd}}$ & $7.56 \pm 1.13^{\mathrm{d}}$ \\
\hline Brightness (10) & $9.72 \pm 0.44^{\mathrm{a}}$ & $8.89 \pm 0.93^{\mathrm{ab}}$ & $8.50 \pm 1.27^{\mathrm{bc}}$ & $8.11 \pm 1.27^{\mathrm{bc}}$ & $7.78 \pm 1.09^{c}$ \\
\hline Crumb texture (10) & $9.78 \pm 0.41^{\mathrm{a}}$ & $9.22 \pm 0.62^{\mathrm{ab}}$ & $8.89 \pm 0.96^{\mathrm{ab}}$ & $8.72 \pm 1.35^{\mathrm{b}}$ & $8.67 \pm 1.09^{b}$ \\
\hline Softness (10) & $9.78 \pm 0.43^{\mathrm{a}}$ & $9.17 \pm 0.71^{\mathrm{a}}$ & $9.24 \pm 0.88^{\mathrm{a}}$ & $9.25 \pm 1.20^{\mathrm{a}}$ & $9.30 \pm 1.27^{\mathrm{a}}$ \\
\hline Taste (15) & $14.56 \pm 0.73^{\mathrm{a}}$ & $13.67 \pm 0.90^{\mathrm{ab}}$ & $13.56 \pm 1.10^{\mathrm{ab}}$ & $13.44 \pm 1.17^{\mathrm{ab}}$ & $13.11 \pm 1.54^{b}$ \\
\hline Odor (15) & $14.11 \pm 0.93^{\mathrm{a}}$ & $14.06 \pm 0.88^{\mathrm{a}}$ & $13.78 \pm 1.06^{\mathrm{a}}$ & $13.33 \pm 1.66^{\mathrm{a}}$ & $13.06 \pm 1.55^{\mathrm{a}}$ \\
\hline Total score (100) & $96.27 \pm 2.74^{\mathrm{a}}$ & $89.66 \pm 5.66^{\mathrm{b}}$ & $87.92 \pm 6.20^{\mathrm{b}}$ & $86.13 \pm 8.17^{\mathrm{b}}$ & $84.15 \pm 8.75^{\mathrm{b}}$ \\
\hline
\end{tabular}

D.P = doum powder. Values are mean of ten replicates $\pm \mathrm{SD}$, number in the same row followed by the same letter are not significantly different at 0.05 leve1. 
did not affected on same characteristics of cake compared with control. Meanwhile, it showed an increasing the acceptability in $5 \%$ followed by $10 \%$ levels of substituted cake.

\section{Conclusion}

From this study, it could be concluded that odor and general acceptability of cakes prepared with $5 \%$ and $10 \%$ doum powder were more acceptable and had no adverse effect on quality compared with the control cakes. Textural analysis indicated that firmness of the cakes was decreased and it became moisty due to the effect of doum fruit fiber. Generally, as the amount of doum powder was increased from zero to $20 \%$ of the flour weight in substituted cake, sensory and physicochemical characteristics were altered. Increasing the levels of substitution increased the total fats, crude fiber and ash contents in produced cake. Physical characteristics indicated a reduction in cake volume except for $10 \%$ level of substitution and increased the orange yellow color of the cake crumb.

\section{References}

[1] Fletcher, R. (1997) Listing of Useful Plants of the World. Australian New Crops. http://www.newcrops.uq.edu.au/listing/hyphaenthebaica.htm

[2] Hashem, A.N. (1994) Physicochemical Investigation of the Fruit of Hyphaene thebaica (L) Mart. Growing in Egypt Family Palma. M.Sc. Thesis, Cairo University.

[3] Cook, J.A., Vander Jagt, D.J., Pastuszyn, A.G., Glew, R.S., Millison, M. and Glew, H.R. (2000) Nutritional and Chemical Composition of 13 Wild Plant Foods of Niger. Journal of Food Composition and Analysis, 13, 83-92. http://dx.doi.org/10.1006/jfca.1999.0843

[4] Sharaf, A., Sour, A., Gomaa, N. and Youssef, M. (1972) Some Pharmacological Studies on Hyphaene thebaica Mart Fruits. Qualities Planetarium Matriae Vegetable, 22, 83-90. http://dx.doi.org/10.1007/BF01099739

[5] Betty, H., Coupar, M.I. and Ken, N.G. (2006) Antioxidant Activity of Hot Water Extract from the Fruit of the Doum Palm "Hyphaene thebaica”. Food Chemistry, 98, 317-328. http://dx.doi.org/10.1016/j.foodchem.2005.05.077

[6] Aremu, M.O., Olaofe, O. and Akintayo, T.E. (2006) A Comparative Study on the Chemical and Amino Acid Composition of Some Nigerian Under-Utilized Legume Flours. Pakistan Journal of Nutrition, 5, 34-38. http://dx.doi.org/10.3923/pjn.2006.34.38

[7] Nieman, D.C., Butterworth, D.E. and Nieman, C.N. (1992) Nutrition. WmC. Brown Publishers, Dubugye, 237-312.

[8] Dubois, C. (1978) The Practical Application of Fiber Materials in Bread Production. Baker's Digest, 52, 30-33.

[9] Fondroy, E.B., White, P.J. and Prusa, K.J. (1989) Physical and Sensory Evaluation of Lean White Cakes Containing Substituted Fluffy Cellulose. Cereal Chemistry, 66, 402-404.

[10] Coimbra, M.C. and Jorge, N. (2011) Proximate Composition of Guariroba (Syagrus oleracea), Jeriva (Syagrus romanzoffiana) and Macauba (Acrocomia aculeate) Palm Fruits. Food Research International, 44, 2139-2142. http://dx.doi.org/10.1016/j.foodres.2011.03.032

[11] Eissa, H.A., Ramadan, M.T. and Ali, H.S. (2008) Effect of Natural Extracts from the Fruits of Doum Palm, Carob and Licorice on the Quality and Safety of Apple Slices. Journal of Agricultural Science of Mansoura University, 33, 66096623.

[12] Katalinic, V., Milos, M., Kulisic, T. and Jukic, M. (2006) Screening of 70 Medicinal Plant Extracts for Antioxidant Capacity and Total Phenols. Food Chemistry, 94, 550-557.

[13] Eldahshan, O.A., Ayoub, N.A., Singab, A.B. and Al-Azizi, M.M. (2008) Potential Super Oxide Amino Radical Scavenging Activity of Doum Plam (Hyphaen thebaica L.) Leaves Extract. Records of Natural Products, 2, 83-93.

[14] Eldahshan, O.A., Ayoub, N.A., Singab, A.B. and Al-Azizi, M.M. (2009) Potential Antioxidant Phenalic Metabolites from Doum Leaves. African Journal of Pharmacy and Pharmacology, 3, 158-164.

[15] Kamis, A.B., Modu, S., Zanna, H. and Oniyangi, T.A. (2003) Preliminary Biochemical and Haematological Effects of Aqueous Suspension of Pulp of Hyphaene thebaica (L) Mart in Rats. Biochemistry, 3, 1-7.

[16] Abou-Elalla, F.M. (2009) Antioxidant and Anticancer Activities of Doum Fruit Extract (Hyphaen thebaica). African Journal of pure and Applied Chemistry, 3, 197-201.

[17] Jeong, J.B., Ju, S.Y., Park, J.H., Lee, J.R., Yun, K.W., Kwwon, S.T., Lim, J.H., Chung, G.Y. and Jeong, H.J. (2009) Antioxidant Activity in Essential Oils of Cnidium officinal makino and Ligusticum chuanxion Hart and Their Inhibitory Effects on DNA Damage and Apoptosis Induced by Ultraviolet B in Mammalian Cell. Cancer Epidemiology, 33, 4146. http://dx.doi.org/10.1016/j.canep.2009.04.010 
[18] Matsakidou, A., Blekas, G. and Paraskevopoulou, A. (2010) Aroma and Physical Characteristics of Cakes Prepared by Replacing Margarine with Extra Virgin Olive Oil. LWT-Food Science and Technology, 43, 949-957. http://dx.doi.org/10.1016/j.lwt.2010.02.002

[19] AOAC (2005) Official Methods of Analysis of AOAC International. 18th Edition, AOAC, Washington DC.

[20] AACC (2002) Approved Methods of the American Association of Cereal Chemistry. American Association of Cereal Chemists, Inc, St. Paul.

[21] Singleton, V.L. and Rossi, J.A. (1965) Colorimetry of Total Phenolics with Phosphomolybdic-Phosphotungstic Acid Reagents. American Journal of Enology and Viticulture, 16, 144-158.

[22] Tepe, B., Daferera, D., Sokmen, A., Sokme, M. and Polissiou, M. (2005) Antimicrobial and Antioxidant Activities of the Essential Oil and Various Extracts of Salivia tomentosa Miller (Lamiaceae). Food Chemistry, 90, 333-340. http://dx.doi.org/10.1016/j.foodchem.2003.09.013

[23] Bourne, M.C. (2003) Food Texture and Viscosity: Concept and Measurement. Elsevier Press, New York/London.

[24] McGurie, R.G. (1992) Reporting of Objective Color Measurements. HortScience, 27, 1254-1255.

[25] Bennion, E.B. and Bamford, G.S. (1983) The Technology of Cake Making. Leonard Hill Books, Great Britain by Builling and Son's Ed., London, 241 p.

[26] Holloway, W.D. and Grieg, R. (1984) Water Holding Capacity of Hemicelluloses from Fruits, Vegetables and Wheat Bran. Journal of Food Science, 49, 1632-1633. http://dx.doi.org/10.1111/j.1365-2621.1984.tb12867.x

[27] Shouk, A.A. and Ramadan, M.T. (2007) Effect of Defatted Rice Bran Addition on the Quality of Pan Bread and Biscuit. Minufiya Journal of Agricultural Research, 32, 1019-1036.

[28] Abd El-Latteef, B.M., Zaghloul, M.M. and El-Hofi, A.A. (2001) Physical and Biological Evaluation of Biscuits Made by Using Oils from Borga, Linseed and Sesame Seed as Sources of Omega-3 and Omega-6 Polyunsaturated Fatty Acid. Proceedings of the 1st Conference of Role of Biochemistry in Environment and Agriculture, Cairo, 6-8 February 2001, 55-72.

[29] Gedrovica, I. and Karklina, D. (2009) Characteristics of Cakes Enriched with Jerusalem artichoke Powder. Chemian Technology, 3, 50-55. 